J. Amer. Soc. Hort. Sci. 116(1):23-26. 1991.

\title{
Cold Hardiness of Various Provenances of Flame, Roseshell, and Swamp Azaleas
}

\author{
Norman E. Pellett', Nancy Rowan', and John Aleong ${ }^{2}$ \\ University of Vermont, Burlington, VT 05405 \\ Additional index words. cold acclimation, hardiness, ecotype, supercooling, Rhododendron calendulaceum, \\ Rhododendron prinophyllum, Rhododendron viscosum
}

\begin{abstract}
Florets of eight provenances representing three native North American azalea species [Rhododendron calendulaceum (Michx.) Torr., R. prinophyllum (Small) Millais, and $R$. viscosum (L.) Torr.] being grown in Burlington, Vt., were compared during three seasons for cold hardiness by laboratory freezing during cold acclimation. There was a large variability in the number of florets killed within an inflorescence in response to freezing temperatures. Cold hardiness of florets of the three species ranked, from most to least hardy, were $R$. viscosum, $R$. prinophyllum, and $R$. calendulaceum. Some differences were noted in cold hardiness of florets of provenances, but these were not necessarily related to latitude or elevation of origin. Cold hardiness of most provenances showed a significant linear relationship with the daily mean temperature of the 3 days preceding freezing tests. Ambient temperatures just before subfreezing test temperatures may affect winter injury more than provenance differences for these species.
\end{abstract}

Flame azalea, Rhododendron calendulaceum, roseshell azalea, $R$. prinophyllum, and swamp azalea, $R$. viscosum, occur naturally in the mountainous and nearby regions of the eastern United States. The flame azalea was reported as far north as the lower Hudson valley and from the Catskill region southward along the mountains in New York (House, 1918). Lee (1965) reported the flame azalea from Pennsylvania and Ohio in the north to Georgia in the Appalachians and the Piedmont above the fall line. Swamp azalea was frequent in wetlands from Maine to Ohio, Arkansas, and south to Florida according to House (1918), but in New York it was rare or infrequent north of the Atlantic coastal region. Bowers (1960) reported the swamp azalea from southwest Maine in the north to South Carolina and west to Ohio and western Tennessee.

$R$. prinophyllum, reported as $R$. canescens, was observed from New Hampshire and eastern and southern New York south to Florida and Louisiana (House, 1918). Bowers (1960) reported it in New Hampshire, Vermont, New York, and Quebec in the north, south to southern Virginia, and west to Ohio, southern Illinois, and western Tennessee.

The natural range of these azaleas is widespread and they occur at many elevations from near sea level up to $\approx 1600 \mathrm{~m}$. While these plants are prevalent in many regions, urbanization and accompanying development are reducing the diversity of populations.

Pellett and Alpert $(1988,1989)$ showed variation in flowering dates and floral characteristics and the quality and timing of autumn foliage coloration for some of these provenances. Studies in Minnesota have shown that deciduous azalea florets survive winter by supercooling to resist ice nucleation at temperatures as low as - 40C (Graham and Mullin, 1976a). Laboratory freezing of evergreen rhododendron inflorescences has been useful in comparing cultivar differences in cold hardiness (Pellett and Holt, 1981).

The purpose of our study was to compare cold acclimation

Received for publication 5 Feb. 1990. We thank Diantha Howard for her assistance in statistics and computer programming and David Heleba for his help in manuscript preparation. This work was supported by the Vermont Agricultural Experiment Station and the Vermont Plantsmen's Association. The cost of publishing this paper was defrayed in part by the payment of page charges. Under postal regulations, this paper therefore must be hereby marked advertisement solely to indicate this fact.

'Dept. of Plant and Soil Science.

${ }^{2}$ Dept. of Mathematics and Statistics. within and among the inflorescences of provenances of three native North American azaleas during late autumn-early winter.

\section{Materials and Methods}

Seeds of these species were collected from northern regions and higher elevations where they were endemic (Table 1). $R$. viscosum interbreeds freely with $R$. arborescens and sometimes with $R$. calendulaceum, producing floral characteristics that are intermediate between the parents (Bowers, 1960; Lee, 1965). Our collected species are consistent with descriptions of Rehder (1956). R. viscosum from BRP 408 North Carolina (Table 1) may be $R$. viscosum montanum whose corolla is more highly glandular; the variety somewhat stoloniferous and lower in height than the species (Lee, 1965; Rehder, 1956).

Knowledge of the cold hardiness of these provenances may help identify the diversity and adaptation of these species. Plant breeders may use this information in choosing desired characteristics.

Seeds of each provenance of three species were collected from six or more plants within each natural habitat during 1978 through 1980 (Table 1). Seeds were germinated in the greenhouse, grown in outdoor ground beds for 2 years, then planted outdoors in loamy-sand soil at the Univ. of Vermont Horticultural Research Center in South Burlington, Vt. (latitude $44^{\circ} 29^{\prime}$; elevation $34 \mathrm{~m}$ ). Each plot of 24 plants was replicated three times in a lattice square design. Plants were mulched with mixed

Table 1. Location of native azaleas used in this study.

\begin{tabular}{lccr}
\hline $\begin{array}{c}\text { Species and } \\
\text { provenance }\end{array}$ & $\begin{array}{c}\text { Latitude } \\
\left({ }^{\circ} \mathrm{N}\right)\end{array}$ & $\begin{array}{c}\text { Longitude } \\
\left({ }^{\circ} \mathrm{W}\right)\end{array}$ & $\begin{array}{r}\text { Elevation } \\
(\mathrm{m})\end{array}$ \\
\hline R. calendulaceum (flame) & & & \\
BRPz 408, N.C. & $35^{\circ} 34^{\prime}$ & $82^{\circ} 45^{\prime}$ & 1499 \\
BRP 338, N.C. & $35^{\circ} 50^{\prime}$ & $82^{\circ} 03^{\prime}$ & 1126 \\
Kerens, W.Va. & $39^{\circ} 02^{\prime}$ & $79^{\circ} 49^{\prime}$ & 686 \\
$R$. prinophyllum (roseshell) & & & \\
Dolly Sods, W.Va. & $38^{\circ} 57^{\prime}$ & $79^{\circ} 22^{\prime}$ & 1220 \\
Wendell, Mass.y & $42^{\circ} 34^{\prime}$ & $72^{\circ} 26^{\prime}$ & 335 \\
Lake Dunmore, Vt. & $43^{\circ} 53^{\prime}$ & $73^{\circ} 04^{\prime}$ & 183 \\
R. viscosum (swamp) & & & \\
BRP 408, N.C. & $35^{\circ} 24^{\prime}$ & $82^{\circ} 45^{\prime}$ & 1499 \\
Packardville, Mass. & $42^{\circ} 21^{\prime}$ & $72^{\circ} 23^{\prime}$ & 280 \\
\hline
\end{tabular}

${ }^{2} \mathrm{BRP}=$ milepost number on the Blue Ridge Parkway in North Carolina.

${ }^{y}$ Wendell State Forest in Massachusetts. 
hardwood and softwood sawdust from a local mill and irrigated daily until early September each year by means of a trickle irrigation system. Each plant was fertilized with $\approx 25 \mathrm{~g}$ of ammonium sulfate and $20 \mathrm{~g}$ of $15 \mathrm{~N}-6.5 \mathrm{P}-12.5 \mathrm{~K}$ (15-15-15) 15 May and 1 July of each year.

Terminal inflorescences with attached 1-cm stems were collected from several plants in all replicates during November and December of each test year from 1986 to 1988 . Four or six of the pooled inflorescences of plants from each provenance were randomly placed in test tubes and frozen at three-degree intervals between - 14 and - 32C. Progressively lower temperatures were used on successive sampling dates to accommodate expected increasing cold hardiness. Thermocouples were inserted into four inflorescences, not otherwise used, to measure temperature.

Inflorescences were not nucleated with ice during freezing tests. Ashworth and Davis (1987) observed that partially hardened peach buds nucleated with ice were more likely to deepsupercool than non-nucleated buds. Nucleated, more hardy buds did not supercool more than non-nucleated buds. Recommending nucleation during freezing tests, Ashworth et al. (1985) hypothesized that redistribution of ice to the bud axis and scales after nucleation promoted greater supercooling in the flower buds. However, Kaku et al. (1982) observed that water content of azalea bud scales did not increase nor floret water content decrease during freezing of the florets. Therefore, it is unclear whether the practice of nucleating florets during laboratory freezing creates internal moisture conditions similar to outdoor freezing.

Stoppered tubes containling inflorescences were submerged to within $2 \mathrm{~cm}$ of the top in a freezer-contained alcohol bath at 0C. The freezer-bath temperature was lowered to $6 \mathrm{C}$, held for $1 \mathrm{hr}$, then lowered again to the test temperatures at the rate of 8 to $10 \mathrm{C} / \mathrm{hr}$, a rate of temperature decline that caused no increase in floret injury (Graham and Mullin, 1976a). As inflorescences reached the test temperature, tubes were placed at the same depth in a plastic container of alcohol at the test temperature and removed to a refrigerator at $2 \mathrm{C}$ and held for 12 to $24 \mathrm{hr}$. Inflorescences in test tubes were covered with moist paper toweling to maintain high humidity, placed in closed polyethylene bags, and put into an incubator at 24C. After 2 days, the inflorescences were dissected and the number of dead (black) and live (white) florets were counted.

The cold hardiness level was expressed as $\mathrm{T}_{50}$ (temperatures killing $50 \%$ of florets) calculated for each provenance on each sampling date by using the logistic regression method (J. Aleong, 1989, unpublished; Sanathanan et al., 1987). The $\mathrm{T}_{50}$ values for each provenance were compared within a species for each date by the $95 \%$ confidence limits from the logistic regression based on Student's $t$ test. To determine the relationship between cold hardiness level and prior outdoor temperatures, we regressed the $\mathrm{T}_{50}$ values on the mean temperature for 3 days before sampling and compared the regression coefficients for provenances of each species. Slopes for the regression lines for provenances were tested for equality of slopes.

\section{Results and Discussion}

There was a wide range in the number of florets killed within inflorescences at any temperature that resulted in injury (Table 2 ). The weighted means were adjusted for the unequal number of florets per inflorescence. The standard errors ranged from 6.6 to 8.5 for provenances of roseshell azalea (Table 2). All sampling dates showed a wide range of percentage of florets
Table 2. Percent dead florets per inflorescence ${ }^{z}$, standard errors, and range for three provenances of Rhododendron prinophyllum (roseshell azaleas) after laboratory freezing at temperatures causing injury.

\begin{tabular}{lcc}
\hline Provenance & Mean \pm SE & Rangey \\
\hline 23 Nov. 1988, -20 C & & \\
Dolly Sods, W.Va. & $38.2 \pm 8.5$ & $0-100$ \\
Wendell, Mass. & $40.4 \pm 7.2$ & $25-75$ \\
Lake Dunmore, Vt. & $65.9 \pm 7.2$ & $38-100$ \\
12 Dec. 1988, -26C & & \\
Dolly Sods, W.Va. & $23.8 \pm 6.7$ & $0-75$ \\
Wendell, Mass. & $29.0 \pm 8.3$ & $0-67$ \\
Lake Dunmore, Vt. & $43.9 \pm 7.9$ & $17-100$ \\
27 Dec. 1988, -23C & & \\
Dolly Sods, W.Va. & $47.6 \pm 7.8$ & $29-75$ \\
Wendell, Mass. & $26.1 \pm 6.6$ & $0-71$ \\
Lake Dunmore, Vt. & $54.2 \pm 7.3$ & $38-100$ \\
\hline
\end{tabular}

${ }^{z}$ Weighted means for six inflorescences.

${ }^{y}$ Range $=$ maximum percentage minus minimum percentage

killed per inflorescence for all provenances of all species (data not shown). At temperatures causing injury, some inflorescences contained no injured florets while others had a portion of the florets killed, a condition that was observed on all sampling dates for all provenances. This observation is consistent with field observations by the senior author who has often noted that some inflorescences of azaleas fail to open a single floret while others open some or all of their florets. Dissection of the failed flower buds from both laboratory and field freezing showed blackened florets that are not apparent from the uninjured bud scales.

The wide range in the percentage of dead florets was consistent with George et al. (1974) who observed that nucleation of individual florets ranged fro -13.2 to $-22.8 \mathrm{C}$ in the same inflorescence, temperatures presumed to kill florets. Graham and Mullin (1976a) observed that temperatures that kill florets ranged between -16.9 and $-26.9 \mathrm{C}$.

While there appeared to be differences in the $\mathrm{T}_{50}$ among the provenances of each species, most were not significant over the nine sampling dates (Table 3 ). The $\mathrm{T}_{50}$ for roseshell azalea from Lake Dunmore, Vt., was greater than the other two provenances on eight of nine dates, suggesting that the Lake Dunmore provenance was less cold hardy than those from Wendell State Forest, Mass., or Dolly Sods, W.Va.

Flame azalea showed no significant differences in $\mathrm{T}_{50}$ among provenances (Table 3 ). The swamp azalea showed significantly lower $\mathrm{T}_{50}$ for the North Carolina source compared to the Massachusetts source on one (30 Dec. 1989) of eight sampling dates.

Other studies have shown that latitude of origin for perennial plants has a significant impact on the timing and degree of cold acclimation (Håbjørg, 1988; Klebesadel, 1985). Also, elevation influences the cold hardiness of native azaleas (Bower, 1965). However, our study does not show a clear relationship between the effects of latitude and elevation on cold acclimation. There may have been a confounding influence between elevation and latitude effects on cold hardiness of the provenances in this study. Most of the northern provenances were collected from lower elevations, possibly reducing latitudinal effects on cold hardiness.

Flame azalea had a higher percentage of florets killed than roseshell azalea on seven of eight sampling dates, differences that were significant on five of the dates (Table 4). The swamp azalea had significantly less floret injury than flame azalea on 
Table 3. Cold hardiness of azalea florets, ${ }^{\circ} \mathrm{C}\left(\mathrm{T}_{50}{ }^{2}\right) .{ }^{y}$

\begin{tabular}{|c|c|c|c|c|c|c|c|c|c|}
\hline \multirow{2}{*}{$\begin{array}{l}\text { Species and } \\
\text { provenance }\end{array}$} & \multicolumn{3}{|c|}{1986} & \multicolumn{3}{|c|}{1987} & \multicolumn{3}{|c|}{1988} \\
\hline & 25 Nov. & 9 Dec. & 30 Dec. & 24 Nov. & 1 Dec. & $30 \mathrm{Dec}$. & 23 Nov. & 12 Dec. & 27 Dec. \\
\hline \multicolumn{10}{|c|}{ R. calendulaceum (flame) } \\
\hline BRP 408, N.C. & $-20.2 \mathrm{a}$ & $-24.7 \mathrm{a}$ & $-24.8 \mathrm{a}$ & $-25.8 \mathrm{a}$ & $-22.9 \mathrm{a}$ & $-28.1 \mathrm{a}$ & -19.5 a & $-23.2 \mathrm{a}$ & $-21.5 \mathrm{a}$ \\
\hline BRP 338, N.C. & $<-20.0$ & $-25.1 \mathrm{a}$ & $<-25.0$ & $-25.0 \mathrm{a}$ & $-20.0 \mathrm{a}$ & $-25.3 \mathrm{a}$ & $-14.7 \mathrm{a}$ & $-20.9 \mathrm{a}$ & $<-23.0$ \\
\hline Kerens, W.Va. & $-21.1 \mathrm{a}$ & $-26.7 \mathrm{a}$ & $-21.0 \cdot \mathrm{a}$ & $-29.7 \mathrm{a}$ & $-19.7 \mathrm{a}$ & $-27.1 \mathrm{a}$ & $-18.6 \mathrm{a}$ & $-25.1 \mathrm{a}$ & $-22.7 \mathrm{a}$ \\
\hline \multicolumn{10}{|c|}{ R. prinophyllum (roseshell) } \\
\hline Dolly Sods, W.Va. & $-21.0 \mathrm{a}$ & $-26.6 \mathrm{a}$ & $-24.8 \mathrm{a}$ & $-25.9 \mathrm{a}$ & $-23.1 \mathrm{a}$ & $-31.6 \mathrm{a}$ & $-20.0 \mathrm{a}$ & $-25.6 \mathrm{a}$ & $-23.1 \mathrm{a}$ \\
\hline Wendell, Mass. & $-22.0 \mathrm{a}$ & $-27.1 \mathrm{a}$ & $-26.1 \mathrm{a}$ & $>-26.0$ & $-24.3 \mathrm{a}$ & $-32.2 \mathrm{a}$ & $-20.0 \mathrm{a}$ & $-23.8 \mathrm{a}$ & $-21.8 \mathrm{a}$ \\
\hline Lake Dunmore, Vt. & $-20.1 b$ & $-23.2 b$ & $-25.0 \mathrm{a}$ & $-23.9 \mathrm{a}$ & $-17.5 b$ & $-25.0 b$ & $-18.8 \mathrm{a}$ & $-21.6 \mathrm{a}$ & $-23.0 \mathrm{a}$ \\
\hline $\begin{array}{l}\text { R. vlscosum (swamp) } \\
\text { BRP 408, N.C. }\end{array}$ & $<-25.0$ & $-30.5 a$ & $-34.1 \mathrm{a}$ & $-28.4 \mathrm{a}$ & $-24.3 \mathrm{a}$ & $-34.2 \mathrm{a}$ & $-20.0 \mathrm{a}$ & $-30.4 a$ & -.. \\
\hline Packardville, Mass. & -23.7 & $-29.4 \mathrm{a}$ & $-29.0 \mathrm{~b}$ & $-26.1 \mathrm{a}$ & $-25.2 \mathrm{a}$ & $-32.6 \mathrm{a}$ & $-19.9 a$ & $-32.1 \mathrm{a}$ & $\cdots$ \\
\hline
\end{tabular}

${ }^{2} \mathrm{~T}_{50}=$ Temperature killing $50 \%$ of the florets was calculated by logistic regression. Means were separated within column for each species by comparing 95\% confidence limits using Student's $t$ statistic.

${ }^{\mathrm{y}} \mathrm{T}_{50}$; when > is used, the $\mathrm{T}_{50}$ is greater (hardiness less) than this highest temperature used for freezing; when < is used, the $\mathrm{T}_{50}$ is lower (hardiness greater) than this lowest temperature used for freezing.

Table 4. Percentage of dead azalea florets at selected temperatures. ${ }^{2}$

\begin{tabular}{|c|c|c|c|c|c|c|c|c|c|}
\hline \multirow[b]{4}{*}{ Species } & \multicolumn{3}{|c|}{1986} & \multicolumn{3}{|c|}{1987} & \multicolumn{3}{|c|}{1988} \\
\hline & 25 Nov. & 9 Dec. & 30 Dec. & 24 Nov. & $1 \mathrm{Dec}$. & $30 \mathrm{Dec}$. & 23 Nov. & 12 Dec. & 27 Dec. \\
\hline & \multicolumn{9}{|c|}{ Temperature $\left({ }^{\circ} \mathrm{C}\right)$} \\
\hline & -20 & -26 & -26 & -23 & -20 & -26 & -17 & -26 & -23 \\
\hline & \multicolumn{9}{|c|}{ Dead florets (\%) } \\
\hline $\begin{array}{l}R . \text { calendulaceum (flame) } \\
R . \text { prinophyllum }\end{array}$ & $40.7 \mathrm{a}$ & $49.0 \mathrm{a}$ & $92.0 \mathrm{a}$ & $16.8 \mathrm{ab}$ & $40.9 \mathrm{a}$ & 38.4 a & $41.5 \mathrm{a}$ & $52.8 \mathrm{a}$ & $76.2 \mathrm{a}$ \\
\hline (roseshell) & $27.6 \mathrm{a}$ & $40.9 \mathrm{a}$ & $54.5 \mathrm{~b}$ & $24.8 \mathrm{a}$ & $10.3 \mathrm{~b}$ & $27.9 \mathrm{a}$ & $14.9 \mathrm{~b}$ & $32.5 \mathrm{~b}$ & $44.4 \mathrm{~b}$ \\
\hline R. viscosum (swamp) & $2.5 \mathrm{~b}$ & $15.8 \mathrm{~b}$ & $7.1 \mathrm{c}$ & $5.6 \mathrm{~b}$ & $2.7 \mathrm{~b}$ & $4.9 \mathrm{~b}$ & $15.2 \mathrm{~b}$ & $19.6 \mathrm{~b}$ & $\cdots$ \\
\hline
\end{tabular}

${ }^{2}$ These data are from temperatures showing $<50 \%$ floret injury for most provenances. Means are of 12 or more inflorescences representing all provenances. Means were separated in columns by comparing $95 \%$ confidence limits using Student's $t$ statistic.

seven of eight dates and less injury than roseshell azalea on five dates.

With the exception of $R$. viscosum provenance BRP 408, there was a significant linear relationship $(\mathrm{P}<0.05)$ between $\mathrm{T}_{50}$ and mean daily temperatures for the 3 days before sampling, regardless of the sampling date (Fig. 1). There were no significant differences in slopes of provenances for each of the species ( $P>0.05$, equality of slopes). The relationship between cold hardiness $\left(\mathrm{T}_{50}\right)$ and daily mean temperatures was similar (slopes parallel) for the three provenances of flame and of roseshell azalea and two provenances of swamp azalea.

These data suggest that flower buds of flame and roseshell azalea in late December would survive -20 to $-25 \mathrm{C}$ or below (as observed on 30 Dec. 1987) if several days of subfreezing temperatures preceded the test temperature. Swamp azalea flower buds would be expected to survive lower temperatures $(-30$ to $-35 \mathrm{C})$. This result agrees with plant survival information that recognizes swamp and roseshell azalea as hardy in zone $3(-37.2$ to 28.9C, Arnold Arboretum zone map, Dirr, 1983; Rehder, $1956)$ and flame azalea as hardy in zone 5 ( -23.3 to $-20.6 \mathrm{C})$. However, roseshell azalea flower buds may be less hardy than the zone 3 assigned by Dirr and by Rehder.

Graham and Mullin (1976b) observed that hybrid clones of deciduous azaleas that hardened more rapidly during decreasing temperatures also rehardened rapidly in response to increasing temperatures in midwinter. Similarly, peach flower buds showed increased or decreased cold hardiness during winter in response to mean daily temperatures for 2 days preceding sampling (Proebsting and Andrews, 1982). Changes in midwinter cold hardiness occurred very rapidly in response to air temperatures above or below 0 to $-2 \mathrm{C}$. This same phenomenon appears true for the different provenances of the three species compared here. All three species appeared to deharden rapidly if mean temperatures just before testing were higher than those before the last test. For example, mean daily temperatures increased between the two December sampling dates in 1986 and 1988, but decreased just before sampling in 1987 when the three species developed greater cold hardiness during December (Table 3).

Apparently, the prior ambient temperatures influence the degree to which the florets can supercool, a condition that depends on the ability of florets to lose water from tissues (Graham and Mullin, 1976a; Kaku et al., 1982). Both groups observed lower water content in hardier florets.

Apple xylem parenchyma, like flower buds, hardened and rehardened rapidly during midwinter in response to air temperatures (Hong and Sucoff, 1982). This midwinter response was different from early fall or late winter when the changes in hardiness appeared to be related to photoperiodic control for early fall and to factors associated with late winter bud swell. Xylem did not harden nor deharden rapidly in early fall nor reharden as rapidly in the late winter in response to temperature as during midwinter. Apple xylem and peach buds changed midwinter hardening (supercooling) ability in response to increasing or decreasing temperatures near $0 \mathrm{C}$ and both tissues had reduced ability to reharden when rest was complete and bud development commenced in late winter (Hong and Sucoff, 1982; Proebsting, 1963).

There are similarities in the response of apple xylem and 

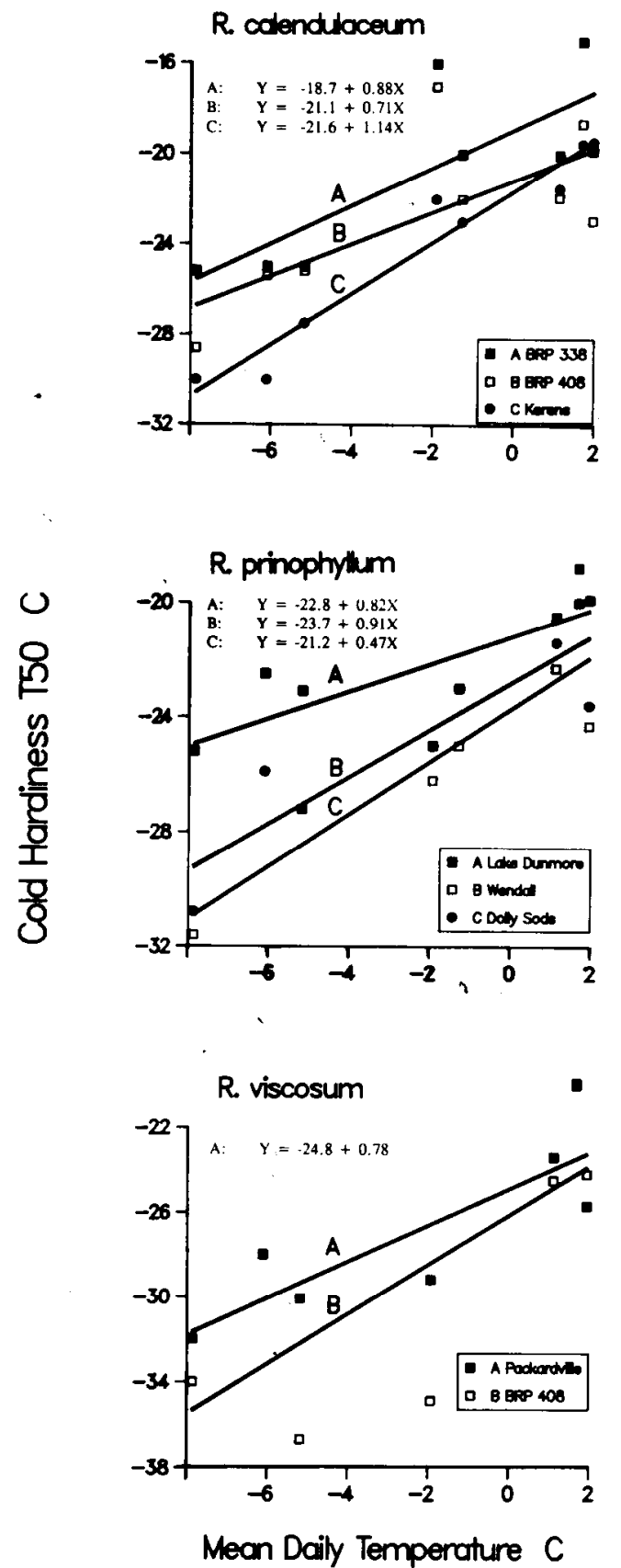

Fig. 1. Regression of cold hardiness of three azalea species on mean daily temperature for 3 days preceding hardiness determination.

peach and azalea flower buds to changes in midwinter hardiness response to ambient temperatures. After a certain stage of cold acclimation is reached, the deep supercooling ability (cold hardiness) of these tissues appears to respond rapidly to temperatures. It appears that the azalea buds of species native to the eastern United States in our study had reached this hardiness stage by the first sampling dates each year, as shown by their ability to change hardiness in response to temperature. Daily mean temperatures before sampling ranged from well below the critical 0 to $-2 \mathrm{C}$ (Hong and Sucoff, 1982; Kaku et al., 1982; Proebsting and Andrews, 1982), resulting in increased hardiness, to above the critical temperature on some late-December dates, resulting in decreased hardiness.

The number of florets killed at our test temperatures showed a large range for all provenances on all test dates. This phenomenon is consistent with field observations of the senior author and reports for other azaleas. The cold hardiness level of all provenances responded readily to mean daily temperatures during the three days prior to freezing. Cold hardiness did not necessarily increase from mid-November through December, but responded readily to recent temperatures. There appeared to be limited differences in cold hardiness among the provenances of the same species. Cold hardiness of inflorescences of the three provenances each of flame azalea was slightly lessor equal to roseshell azalea and generally less than the two provenances of swamp azalea.

\section{Literature Cited}

Ashworth, E.N. and G.A. Davis. 1987. Influence of ice nucleation temperature on the freezing of peach flower buds. HortScience 22:923925 .

Ashworth, E. N., J.A. Anderson, G.A. Davis, and G.W. Lightner. 1985. Ice formation in Prunus persica under field conditions. J. Amer. Soc. Hort. Sci. 110:322-324.

Bowers, C.G. 1960. Rhododendrons and azaleas. Macmillan, New York.

Dirr, M.A. 1983. Manual of woody landscape plants. (3rd cd.) Stipes Publishing, Champaign, Ill.

George, M. F., M.J. Burke, and C.J. Weiser. 1974. Supercooling in overwintering azalea flower buds. Plant Physiol. 54:29-35.

Graham, R.P. and R. Mullin. 1976a. The determination of lethal freezing temperatures in buds and stems of deciduous azalea by a freezing curve method. J. Amer. Soc. Hort. Sci. 101:3-7.

Graham, R.P. and R. Mullin. 1976b, A study of flower bud hardiness in azalea. J. Amer. Soc. Hort Sci. 101:7-10.

Håbjørg, A. 1988. Ecophysiology and selection of European urban trees. HortScience 23:539-542.

Hong, S.G. and E. Sucoff. 1982. Temperature effects on acclimation and deacclimation of supercooling in apple xylem, p. 341-356. In: P.H. Li and A. Sakai (eds.). Plant cold hardiness and freezing stress. vol. 2. Academic, New York.

House, H.D. 1918. Wild flowers of New York. Part 2. Univ. of New York State Museum. Albany. p. 201.

Kaku, S., M. Iwaya, and K.B. Jeon. 1982. Supercooling ability and cold hardiness of Rhododendron flower buds with reference to winter water relations, p. 357-366. In: P.H. Li and A. Sakai (eds.) Plant cold hardiness and freezing stress. vol. 2. Academic, New York.

Klebesadel, L.J. 1985. The critical importance of north-latitude adaptation for dependable winter survival of perennial plants in Alaska. Agroborealis 17(1):21-30.

Lee, F.P. 1965. The azalea book. 2nd ed. D. van Nostrand, Princeton, N.J.

Pellett, N.E. and K. Alpert. 1988. Flowering of flame and roseshell azaleas. J. Amer. Rhododendron Sot. 42(1):23-25.

Pellett, N.E. and K. Alpert. 1989. Fall foliage coloration of native northeastern azaleas. J. Amer. Rhododendron Sot. 43(1):8-11.

Pellett, N.E. and M.A. HoIt. 1981. Comparison of flower bud cold hardiness of several cultivars of Rhododendron spp. HortScience 16:675-676.

Proebsting, E. L., Jr. 1963, The role of air temperatures and bud development in determining hardiness of dormant Elberta peach fruit buds. Proc. Amer. Soc. Hort. Sci. 83:259-269.

Proebsting, E. L., Jr. and P.K. Andrews. 1982. Supercooling and Prunus flower bud hardiness, p. 529-539. In: P.H. Li and A. Sakai (eds). Plant cold hardiness and freezing stress. vol. 2. Academic, New York.

Rehder, A. 1956. Manual of cultivated trees and shrubs. Macmillan, New York.

Sanathanan, L. P., E.T. Gade, and N.L. Shipkowitz. 1987. Trimmed logit method for estimating the ED50 in quantal bioassay. Biometrics 43(4):825-832. 